\title{
URSZULA KNOP
}

Politechnika Częstochowska, Biblioteka Główna

\section{Komunikacja z klientem $\mathrm{w}$ bibliotece akademickiej - ujęcie psychologiczne}

\begin{abstract}
STreszczenie. W artykule ukazano różne aspekty związane z komunikacją między ludźmi, zwrócono uwagę na kontakt klienta z biblioteką przez nowe technologie. Przybliżono właściwości komunikowania. Omówiono komunikację zapewniającą jednostce odczucie komfortu psychicznego w komunikacji bezpośredniej, przez telefon, za pośrednictwem poczty e-mail. Scharakteryzowano współczesnego klienta biblioteki. W bibliotece akademickiej uwzględniono obsługę klienta w czytelni oraz kontakt klienta za pomocą katalogu OPAC.
\end{abstract}

SŁowA KLuczowe: komunikacja bezpośrednia, komunikacja przez telefon, e-mail, OPAC, biblioteka akademicka.

Obecnie w bibliotece akademickiej jak w każdej innej organizacji komunikacja pomiędzy ludźmi nabiera znaczenia. Równie ważne są komunikacja interpersonalna (bezpośrednia), komunikowanie przez telefon, nowoczesne technologie. Istnieje potrzeba znajomości i przestrzegania przyjętych zasad dobrej komunikacji międzyludzkiej, psychologicznego podejścia do ludzi. Zwraca się uwagę na kontakt z klientem, otwarcie na klienta, jego społeczne zaistnienie.

Klasyczny model porozumiewania się ludzi przyjęty $\mathrm{w}$ teorii nauk o komunikacji przedstawia elementarne składniki przekazu: „kto mówi?, co mówi?, za pośrednictwem jakiego kanału mówi?, z jakim skutkiem mówi?"1. Logiczne powiązanie poszczególnych składników z uwzględnieniem zależności występujących między nimi wpływa na kształt i skuteczność procesu komunikacji.

Istotne jest dostrzeżenie, że zarówno komunikacja międzyludzka, jak i kontakt z klientem przez nowoczesne technologie kształtują wizerunek

${ }^{1}$ H. Lasswell, The Structure and Function of Communication in Society, w: L. Bryson, The Communication of Ideas, New York 1948, cyt. za: A. Rataj, Komunikacja w organizacji [I], http://www.racjonalista.pl [dostęp: 14.04.2016]. 
organizacji, sprzyjają optymalizacji obsługi klienta, wpływają na jednostkę. Wpływ ten może wyzwalać różne emocje, zarówno pozytywne, negatywne, jak i obojętność uczestników komunikacji, a przez to zachęcać lub zniechęcać do korzystania z biblioteki, do współpracy. Można rozbudzać inne niż wcześniej potrzeby.

Bibliotekarze i użytkownicy - wszyscy są klientami w zależności od sytuacji. W artykule przedstawiam właściwości procesu komunikowania, komunikację bezpośrednią przez telefon, e-mail. Charakteryzuję klienta biblioteki. W bibliotece akademickiej uwzględniam komunikację z klientem w czytelni i kontakt klienta z biblioteką przez katalog OPAC.

\section{Właściwości procesu komunikowania}

Wiedza o komunikacji między ludźmi obejmuje różne aspekty, w tym teorię w zakresie właściwości procesu komunikowania się. Wiadomo, że jest to proces kreatywny, w którym ludzie w niepowtarzalny i przypisany tylko im sposób nadają i odbierają przekaz. Kolejne cechy określające komunikowanie to dynamiczność, ciągłość, interakcyjność, nieuchronność ${ }^{2}$. Dynamiczność stoi w opozycji do statyczności, co oznacza, że dzięki komunikowaniu następuje transfer informacji, wiedzy. Z psychologicznego punktu widzenia odbiór informacji i wiedzy jest jednym z ważniejszych czynników stymulujących rozwój intelektualny ludzi. Nieprzerwane pozyskiwanie nowych wiadomości, o ile są one rzetelne i prawdziwe, zapobiega cofaniu się jednostki, powoduje stały wzrost wiedzy, daje zrozumienie zachodzących zmian $\mathrm{w}$ otoczeniu, w konsekwencji poczucie pewności siebie $\mathrm{w}$ sytuacji pracy oraz $\mathrm{w}$ otoczeniu bliższym i dalszym. Im więcej informacji i wiedzy ludzie pozyskuja, tym bardziej pamięć jednostki rozbudowuje się i uaktywnia. Ciągłość wynika m.in. z faktu nieustannego komunikowania się w rozwiązywaniu problemów jednostki społecznej. Interakcyjność polega na sprzężeniu zwrotnym, czyli istnieniu akcji i reakcji pomiędzy uczestnikami tego procesu. Kolejna z cech komunikowania - nieuchronność - wiąże się z koniecznością przekazywania sobie nawzajem informacji i wiedzy, bez względu „na uświadamiane lub nieuświadamiane zamiary"3 ludzi, niejako stanowi o podstawie bytu i rozwoju jednostki w społeczeństwie.

\footnotetext{
${ }^{2}$ B. Dobek-Ostrowska, Podstawy komunikowania społecznego, Wrocław 2004, s. 14.

${ }^{3}$ Ibidem.
} 


\section{Komunikacja bezpośrednia, przez telefon, e-mail}

Rozpatrując komunikację bezpośrednią (bez udziału środków telekomunikacyjnych), zauważa się szczególną odmienność tej formy porozumiewania się ludzi od pozostałych kanałów komunikacji. Inność ta polega na stwarzaniu swoistego klimatu przez wzajemne oddziaływanie na siebie uczestników komunikacji wszystkimi zmysłami: mowa, słuch, wzrok, dotyk, które w zasadniczy sposób regulują procesy poznawcze, takie jak myślenie, pamięć, spostrzeganie, uwaga, wyobraźnia. Świadomość jednostki, że bezpośrednia komunikacja między ludźmi stanowi proces psychologiczny, wymaga odpowiedniego podejścia do kontaktów z innymi.

Właściwe podejście wyznaczone jest przez sposób zachowania, w tym postawę, gesty, słowa: „utrzymywanie kontaktu wzrokowego z rozmówca; lekkie przechylanie głowy; pochylanie się lekko do przodu; delikatne przytakiwanie [...], wolny ruch sygnalizuje słuchanie i zrozumienie, a szybkie przytakiwanie oznacza zgodę; sformułowania typu ciekawe, jasne, rozumiem, zgadzam się" ${ }^{\prime \prime}$ Utrzymywanie kontaktu wzrokowego w pozytywnym znaczeniu polega na ciepłych, szczerych, chwilowych spojrzeniach dających odczucie zainteresowania rozmówca, nastawienia do niego. Mimika twarzy mówi o emocjach, wyraża smutek, zakłopotanie, powagę, skupienie, zadowolenie, radość. W teorii psychologii „nieustannie potwierdzana jest teza, że człowiek ma tendencję do odzwierciedlania wyrazu twarzy innych" ${ }^{\prime}$, uśmiech wywołuje dobrą energię, nastrój, wpływa na osiagnnięcie celu, eliminuje strach, stres, niepewność rozmówcy. Dobry nastrój jest skutkiem przeżywania pozytywnych emocji. Pozytywne emocje powodują nastawienie na dobrą współpracę. Ważne jest dostrzeżenie, że stwarzają je nie tylko rozmówcy, ale również przedmioty, z którymi mają oni do czynienia. Nie bez znaczenia jest odległość dzieląca komunikujących się ludzi. Zarówno nadawca, jak i odbiorca w tym psychologicznym procesie zajmują określone miejsca, tzw. własną przestrzeń. Powinna ona dawać komfort psychiczny jednostce. W psychologii przyjęto za właściwe odległości dla relacji typu:

- osobista, dla jednostek dobrze znających się dystans od $46 \mathrm{~cm}$ do $76 \mathrm{~cm}$, dla dość dobrze znających się od $76 \mathrm{~cm}$ do $120 \mathrm{~cm}$,

- społeczna, dla jednostek nieznających się dość dobrze dystans od $1,2 \mathrm{~m}$ do $3,7 \mathrm{~m}$,

- publiczna, dla nieznanej większej publiczności dystans od 3,7 $\mathrm{m}^{6}$.

${ }^{4}$ S. Trzeciak, Coaching marki osobistej, czyli kariera lidera, Sopot 2015, s. 151.

${ }^{5} \mathrm{~J}$. Borg, Perswazja: sztuka pozytywnego wptywania na ludzi, przeł. A. Mikołajewska, Warszawa 2011, s. 62.

${ }^{6}$ Ibidem, s. 70. 
Generalnie dystans ten zwiększa się przy słabych relacjach, nieznających się rozmówcach, wraz z ilościowym wzrostem publiczności i może być zróżnicowany w konkretnej sytuacji, w zależności od miejsca przebywania, zamieszkania rozmówców, oczekiwań rozmówców, a nawet przedmiotu dyskursu ${ }^{7}$.

To, jakie miejsce względem siebie zajmują ludzie, można zaobserwować w organizacji. W zależności m.in. od rodzaju instytucji wymienić można różne okoliczności: codzienna praca, spotkanie, szkolenie, zajęcia dydaktyczne, konferencja. Inaczej są uaktywniane bodźce reakcji w komunikacji między dwiema osobami, a inaczej w komunikacji grupowej. O ile w pierwszym przypadku odległość pomiędzy rozmówcami zmniejsza się na skutek wzajemnej pozytywnej oceny, wzajemnego zrozumienia (wymienia się także zażyłość) ${ }^{8}$, o tyle $\mathrm{w}$ relacjach grupowych jednostka prowadząca szkolenia bądź zajęcia dydaktyczne zazwyczaj zachowuje określoną stałą odległość pomiędzy sobą a grupa, bez względu na odczuwane sympatie czy antypatie. Na uwagę zasługuje konieczność zachowania większej odległości z jednostką o wyższym statusie, która z własnej inicjatywy może tę odległość zmniejszyć.

W każdej sytuacji ważna jest komunikatywność osoby, to, czy posiada ona rzeczywistą wiedzę o tym, o czym mówi, czy mówi w sposób przekonujący, czy ma umiejętność przekazu odbiorcy indywidualnemu, grupowemu. Dobry rozmówca potrafi zainteresować innych, przekazać istotne informacje, wyeksponować informację najważniejszą, wysłuchać innych ze zrozumieniem, nie przerywając i nie komentując przekazu.

Próba oceny powodzenia komunikacji interpersonalnej wymaga spojrzenia na wszystkie jednostki biorące udział w tym procesie. W komunikacji grupowej typu szkolenie czy zajęcia dydaktyczne dobra komunikacja oceniana jest na podstawie aktywności wszystkich uczestników - ludzi, którzy „sprawiają że coś się dzieje, obserwuja jak coś się dzieje, nawet nie wiedzą że coś się dzieje, którym przydarzają się różne rzeczy" ${ }^{\prime \prime}$. Trudno jednoznacznie odpowiedzieć, dlaczego ludzie są mniej lub bardziej aktywni w kontaktach interpersonalnych. Powody psychologiczne są często subiektywne, ulotne i mogą być trudne do rozpoznania.

Pobudzeniu aktywności jednostki w sytuacji pracy sprzyja zrozumienie istoty własnej reakcji na problemy stanowiące przedmiot spotkania, konferencji, które przez innych nie zostały zauważone, a powinny być

7 E. Griffin, Podstawy komunikacji społecznej, przeł. O. i W. Kubińscy, M. Kacmajor, Gdańsk 2003, s. 103-108.

8 Ibidem, s. 108.

9 Ibidem, s. 260. 
omówione czy rozwiązane. Aktywność wyrażona w przekazaniu sugestii, zadawaniu konkretnych pytań sprzyja dyskusji, generowaniu wiedzy, myśleniu o tym, co się dzieje wokół. Włączenie się w dyskusję może wpłynąć na pozytywne postrzeganie jednostki przez uczestników spotkania, konferencji i być znakiem zaangażowania w omawiane sprawy.

Z kolei pytania uczestników w czasie szkolenia, zajęć dydaktycznych, okazane przez nich zadowolenie wpływają na satysfakcję jednostki prowadzącej zajęcia i są potwierdzeniem jej umiejętności interpersonalnych. Zadowolenie uczestników może wynikać z pozyskania użytecznych wiadomości, które zapamiętali. Ilość zapamiętanych informacji świadczy m.in. o skuteczności nadawcy. Zapamiętanie przekazu przez odbiorcę, jak i kontrola własnej percepcji następują przez zwrócenie uwagi na najistotniejsze problemy, nowe terminy, kolejność, utrwalenie tych wiadomości za pomocą powtórzeń ${ }^{10}$. Wpływ na ludzi można wywierać też przez pozostawienie dobrego wrażenia po sobie. Istnieje bowiem zależność między tym, jak nadawca komunikatu postrzega siebie (czy lubi siebie, czy nie lubi siebie, innymi słowy: co myśli sam o sobie, czy chce wykreować siebie jako osobę asertywna, dominującą), a wyobrażeniem o własnej osobie odbiorcy komunikatu. Ważne jest, co nadawca, zdaniem odbiorcy, o nim myśli, czy go akceptuje czy nie, czy zgadza się z nim ${ }^{11}$.

W czasie komunikowania się zachodzą określone relacje między ludźmi. Wiedzę na temat istniejących relacji tworzą m.in. odpowiedzi na powszechnie zadawane pytanie: czy ludzie mają dobry kontakt? (czy jest między nimi dobra komunikacja, czy się chętnie komunikują).

Zwraca się uwagę na czynnik ludzki odgrywający zasadniczą rolę w kształtowaniu komunikacji między ludźmi w organizacji, w tym $\mathrm{z}$ klientem ${ }^{12}$. W codziennej pracy, o ile nie ma z góry ustalonej procedury postępowania $\mathrm{w}$ ściśle określonych kontaktach $\mathrm{z}$ klientem, to pracownik decyduje, w jaki sposób komunikować się z innymi. Należy mieć na uwadze, że komfort psychiczny jednostki warunkowany jest także przez wybór sposobu komunikacji: bezpośrednia rozmowa, telefon, e-mail. Wybór ten nie zawsze jest trafny, istnieją bowiem problemy wymagające:

${ }^{10}$ Por. D.T. Kenrick, S.L. Neuberg, R.B. Cialdini, Psychologia społeczna, przeł. A. Nowak, O. Waśkiewicz, M. Trzebiatowska, M. Orski, Gdańsk 2002, s. 128.

${ }^{11}$ J. Stewart, Komunikacja interpersonalna: kontakt między osobami, w: Mosty zamiast murów: o komunikowaniu się między ludźmi, red. J. Stewart, przeł. J. Suchecki, Warszawa 2002, s. 43.

${ }^{12}$ A. Folga, Wptyw komunikacji interpersonalnej na wizerunek biblioteki, „Biblioteka i Edukacja" 2016, nr 9, http://www.bg.up.krakow.pl/newbie/index.php/bie/article/ view/142 [dostęp: 10.04.2016]. 
- omówienia w bezpośredniej rozmowie zamiast przekazu przez telefon, e-mail, w szczególności w przypadku codziennych spotkań w pracy,

- dodatkowych wyjaśnień, wytłumaczenia różnych zależności drugiej osobie $\mathrm{w}$ rozmowie bezpośredniej lub telefonicznej zamiast listu elektronicznego ${ }^{13}$.

Inaczej niż rozmowa bezpośrednia przebiega przekaz przez telefon. Zgodnie $\mathrm{z}$ ogólnie przyjętymi zasadami dobrze skonstruowana rozmowa telefoniczna składa się z następujących elementów: przywitanie, przedstawienie siebie i w sposób zwięzły, jasny wyjaśnienie tematu sprawy będącej powodem telefonu. Jakość odbierania i przyswajania komunikatów warunkowana jest możliwościami percepcyjnymi jednostki można wyróżnić ludzi szybko lub wolno zapamiętujących wysyłany do nich przekaz. Niepoprawnie sformułowany przekaz skutkuje często niekompletnym zapamiętaniem informacji. Niezrozumiały dla odbiorcy komunikat to również wiadomość bez konkretnego nadawcy. W komunikacji przez telefon wskazane są: wyraźne wypowiadanie słów, zachowanie pauzy pomiędzy przywitaniem a przedstawieniem siebie, czyli podaniem kolejno nazwy instytucji, własnego imienia i nazwiska. Nasuwają się pytania, czy ludzie przedstawiają siebie, odbierając telefon, albo czy przedstawiają się tak, że wiadomo kto z kim rozmawia. Czynniki ułatwiające skuteczne załatwienie sprawy - takie jak ciepły ton głosu, przedstawienie problemu w sposób delikatny, ale konkretny, przyjazny dla rozmówcy - stanowią przyczynek do sukcesu rozmowy, bowiem „kluczem do sukcesu jest to, co mówimy i jak to mówimy"14. Dlaczego? Brak kontaktu wzrokowego sprawia, że informacja odbierana jest jedynie przez receptory słuchu, zatem wrażenie odbiorcy o nadawcy determinuje przede wszystkim usłyszany przez niego przekaz, na który składają się słowa, dźwięki, ton głosu. Dobry przekaz przez telefon wzmacnia zaangażowanie wszystkich zmysłów, zadowolenie wyraża słyszalny uśmiech, a zwykle "[l]udzie nie chcą się uśmiechać do słuchawki ze względu na nieuzasadniony lęk przed tym, że będą się czuć i wyglądać głupio"15. Siłę przekazu osłabia natomiast zbyt długa pauza, która dezorientuje rozmówcę. Wrażenia, jakich doznaje jednostka, zależą od ilości, jakości i czasu trwania bodźców. Innymi słowy, rozmówcy działają wzajemnie na siebie, jakby rozmawiali bezpośrednio. $W$ dobrej komunikacji do zasad savoir vivre należą także: wybieranie właściwej pory dzwonienia,

\footnotetext{
13 J. Borg, op.cit., s. 117.

14 Ibidem, s. 120.

15 Ibidem, s. 119.
} 
w przypadku przerwania połączenia powtórne wykonanie telefonu przez dzwoniącego, zakończenie rozmowy zwrotem grzecznościowym „dziękuję za miłą rozmowę", „dziękuję za telefon”.

Coraz częściej w komunikacji między ludźmi standardem jest e-mail podawany wraz $\mathrm{z}$ imieniem i nazwiskiem. W szczególności w organizacji niektóre sprawy z klientem załatwiane są częściowo lub wyłącznie za pomocą e-maila ${ }^{16}$. E-mail, tak jak wiele innych kanałów komunikacji używanych przez społeczność Internetu, należy do przekazu, w którym nadawca i odbiorca informacji nie obserwują siebie i nie słyszą siebie nawzajem. Dla odbiorcy poczty elektronicznej ważne jest, co przeczyta i zobaczy.

Prawidłowo zredagowany e-mail składa się z kilku podstawowych elementów - są to: temat, pozdrowienie, odwołanie się do wcześniejszego kontaktu, powód pisania, wiadomość, która chcemy przekazać, odwołanie się do załącznika listu elektronicznego, zamykanie rozmowy, nazwisko nadawcy, funkcja, instytucja, telefon kontaktowy. Kontakt telefoniczny może okazać się przydatny przy niwelowaniu niedomówień wynikających z przekazu elektronicznego, mogących powodować dyskomfort psychiczny odbiorcy. Przejrzystości treści służy zachowanie podwójnych odstępów pomiędzy wymienionymi częściami e-maila.

Wiadomo, że ludzie nie zawsze przestrzegają ogólnie przyjętych zasad komunikacji i zachowują się w różny sposób, przekazując sobie informację. Podstawową nieprawidłowością w ocenie rozmówcy jest odwoływanie się do jego cech osobowości, z pominięciem sytuacji, w której może znajdować się jednostka rozmawiająca bezpośrednio, przez telefon lub kontaktująca się za pomocą e-maila. Mogą pojawić się różne okoliczności sprzyjające lub niesprzyjające konstruktywnej rozmowie. Jedną z przyczyn obniżenia poziomu efektywności działania i destrukcyjnego myślenia stanowi nagromadzenie wielu zadań koniecznych do wykonania jednocześnie w krótkim terminie.

Ważna jest świadomość ludzi, że w sytuacji pracy, w szczególności w obsłudze klienta kreują własny wizerunek i pośrednio wizerunek organizacji w wyobraźni klienta, a każda organizacja dba o dobry wizerunek. Wizerunek jest obrazem wszystkich elementów dostarczonych wyobraźni ludzkiej. Nadawca i odbiorca przekazu poddają ocenie pozyskany zasób informacji, wiedzy, wybór sposobu kontaktu, czyli co usłyszą, zobacza, przeczytają. Proces oddziaływania na siebie uczestników komunikacji nie zachodzi wyłącznie w trakcie rozmowy bezpośredniej, przez telefon,

${ }^{16}$ Zob. P. Karwasiński, H. Wesołowska-Mis, Wpływ informatyzacji Biblioteki Uniwersyteckiej w Poznaniu na zmiany organizacyjne i rozwój ustug bibliotecznych, „Biblioteka" 2015, nr 19 (28), s. 174. 
odbioru e-maila. Wiadomo, że rozmówcy pozostawiają po sobie wrażenie dłużej. Badania potwierdzają że „[p]amięć długotrwała grupuje dane we wcześniej wybranych kategoriach"17 i ma wpływ na ocenę kontaktu. Rozpoznawaniem procesów, w których ludzkie myśli, uczucia i zachowania ulegają wpływom innych ludzi, przyczyn różnych zachowań i reakcji w konkretnej sytuacji zajmuje się psychologia społeczna ${ }^{18}$.

\section{Charakterystyka klienta biblioteki}

Najważniejszą i jednocześnie zasadniczą kategorię klientów biblioteki akademickiej stanowią pracownicy naukowi, doktoranci i studenci macierzystej uczelni. Do biblioteki przychodzą jednostki związane z inną uczelnią, uczniowie szkół średnich, inni zainteresowani usługami bibliotecznymi. Oddzielną grupę stanowi zespół ludzi zatrudnionych $\mathrm{w}$ bibliotece.

Od dawna klienci biblioteki akademickiej korzystają z elektronicznych naukowych baz danych, w szczególności z zagranicznych czasopism naukowych. Coraz więcej publikacji naukowych ogólnie dostępnych czytają online. Tendencje rozwoju komunikacji, komunikacji naukowej przez Internet powodują podział klientów na odwiedzających bibliotekę w sposób tradycyjny i online oraz wyłącznie online. Pracownicy naukowi coraz więcej czasu spędzają w specjalistycznych serwisach online typu: baza danych, repozytorium instytucjonalne, Facebook, portal społecznościowy dla naukowców, dzięki którym nawiązują kontakty z innymi użytkownikami informacji naukowej, pozyskują pełne teksty naukowe, udostępniają własne. Drugą specyficzną grupę klientów biblioteki tworzy młode pokolenie biegle posługujące się nowoczesnymi narzędziami w Internecie.

Obserwuje się przewartościowanie działań w komunikacji jednostki z biblioteką akademicką i otoczeniem. Użytkownik przebywa w różnych miejscach w Internecie, gdzie wyrabia swoje przyzwyczajenia. Do jego przyzwyczajeń należy poszukiwanie rozmaitych informacji, zasobów informacyjnych i naukowych bez żadnych ograniczeń. Nie liczy się miejsce, w którym uzyska on dostęp do informacji i wiedzy. Najważniejsza jest szybka i sprawna obsługa przez łatwą komunikację. W sposób zaawansowany korzysta z obsługi klienta w sieci, zwykle ceni wyżej obsługę online od tradycyjnej, określany jest jako gracz informacyjny, przy założeniu, że

${ }^{17}$ E. Griffin, op.cit., s. 134.

${ }^{18}$ E. Aronson, T.D. Wilson, R.M. Akert, Psychologia społeczna: serce i umyst, przeł. A. Bezwińska et al., Poznań 1997, s. 28. 
,jest to termin o bogatszym znaczeniu, konotującym działanie i indywidualność osoby"19. W tym kontekście jednostkę wyróżnia samodzielność, samoorganizowanie. To klient decyduje, kiedy, o której godzinie i gdzie chce zadać pytanie, skorzystać z zasobów bibliotecznych. Przebywając dużo czasu online, odczuwa potrzebę tworzenia i wysyłania treści publicznie dostępnych w sieci, co sprzyja wyrażaniu własnych emocji, przemyśleń, pozwala zaistnieć społecznie w ogólnie dostępnym serwisie.

Często w Internecie klient zwraca uwagę na bibliotekę dzięki:

- różnorodnej e-ofercie,

- wielokanałowemu komunikowaniu się z biblioteka,

- dostępności oferty w wyszukiwarce Google,

- popularyzowaniu usług tam, gdzie najczęściej są użytkownicy informacji naukowej. W komunikacji przez Internet jest „[w]ażne, aby klient wiedział, że w każdym miejscu może zadać pytanie i że w tym samym miejscu uzyska na nie odpowiedź" ${ }^{20}$.

\section{Komunikacja bezpośrednia z klientem w czytelni}

Podstawą prawidłowej obsługi klienta jest nieustanne zainteresowanie nim od chwili jego wejścia do biblioteki. Dlaczego? Dobre maniery, ciepłe przywitanie, uprzejmość, informowanie w sposób szybki, szczegółowy i wyczerpujący - stają się standardem kontaktu z klientem w organizacji. Najogólniej można przyjąć, że w bibliotece komunikacja bezpośrednia (bez udziału środków telekomunikacyjnych) z klientem obejmuje kontakty wzajemne ludzi w niej zatrudnionych oraz pracownika z klientem zewnętrznym. Skierowanie bowiem informacji, prośby lub zapytania bibliotekarza do bibliotekarza powoduje, że bibliotekarz staje się klientem. Bez względu na sytuację zawsze najważniejszy jest klient i dobry z nim kontakt. Ważne, aby w bibliotece nie zachodziło komunikowanie, w którym jednostka otrzymuje informację i niczego się nie dowiaduje, nie wie, o co chodzi ${ }^{21}$. Niezbędne są umiejętności interpersonalne w obsłudze klienta.

${ }^{19}$ Ł. Maciejewska, B. Urbańczyk, Czego oczekuja użytkownicy biblioteki akademickiej w dobie informacji elektronicznej, w: Biblioteka: klucz do sukcesu użytkowników, red. M. Kocójowa, Kraków 2008, seria: ePublikacje Instytutu INiB UJ, 5, s. 43, http://www. inib.uj.edu.pl/wydawnictwa-iinib-uj/seria-3 [dostęp: 10.04.2016].

${ }^{20}$ M. Żukowski, Twoja firma w social mediach: podręcznik marketingu internetowego dla małych i średnich przedsiębiorstw, Gliwice 2016, s. 54.

${ }^{21}$ Por. J. Wojciechowski, O komunikacji nieinformacyjnej, w: Biblioteka i informacja w komunikowaniu, red. M. Kocójowa, Kraków 2000, s. 168. 
Jednym z miejsc bezpośredniej obsługi klienta są czytelnie. W czytelni pracownik najpierw skupia uwagę na kliencie, a w dalszej kolejności na wykonywaniu codziennych zadań typu przygotowanie książki do włączenia na półkę, porządkowanie książek na półkach, inne czynności. Ważna jest aktywność w realizacji wszystkich zadań. Każda jednostka posiada odpowiednia, choć własną strategię działania. Proces konkretyzowania, opracowania i kontroli własnych strategii w dążeniu do wytyczonego celu określono terminem „samoregulacja” ${ }^{22}$. Monitorowanie własnego zachowania pozwala zmieniać sposób obsługi klienta, nastawienie do klienta wewnętrznego i klienta zewnętrznego. Aby cokolwiek zmienić, istotne jest zdefiniowanie miejsca i roli bibliotekarza dyżurującego w czytelni, następnie analiza postępowania i porównanie uzyskanych wyników ze stanem, który chcielibyśmy osiągnąć w komunikacji z klientem.

Bibliotekarz, który zwraca uwagę w czytelni na zachowanie klienta, ma sposobność kodowania w pamięci sposobu korzystania z oferty biblioteki przez klienta. W sytuacji braku zainteresowania zbiorami drukowanymi, dostępnymi komputerami, Internetem i krótkiego pobytu klienta w czytelni bibliotekarz może zmienić podejście do niego i sposób komunikowania się z nim. Świadomość potrzeby dobrej komunikacji z innymi, w tym znajomość właściwości procesu komunikowania, skłania bibliotekarza do działania w kierunku większego zainteresowania klientem. Zadaniem pracownika czytelni jest nawiązanie dialogu z klientem, wyjście naprzeciw jego potrzebom, utrzymanie pozytywnych z nim relacji.

W tym przypadku komunikowanie się przebiega pomiędzy dwiema jednostkami społecznymi. Przekaz informacji klientowi w czytelni powinien być krótki, konkretny, merytoryczny, dotyczyć wyszukiwania książki na półce, w katalogu podręcznym, katalogu online, elektronicznych bazach danych oraz informacji na inny temat. Dlaczego kontakt bibliotekarza z klientem jest niezbędny? Brak wiedzy odczuwany przez klienta w czytelni i zainteresowania ze strony dyżurującego bibliotekarza może powodować w nim uczucie niepewności, odrzucenia przez personel biblioteki, zniechęcenia do korzystania z zasobów naukowych biblioteki. Dobry bibliotekarz posiadający kompetencje informacyjne i komunikacyjne potrafi zmniejszać ograniczenia, lęki wśród klientów poprzez skuteczne informowanie o dostępności i możliwościach korzystania z zasobów bibliotecznych informacyjnych i naukowych ${ }^{23}$ oraz zaoferować

22 D.T. Kenrick, S.L. Neuberg, R.B. Cialdini, op.cit., s. 84.

${ }^{23}$ E. Karwasińska, P. Karwasiński, Kształtowanie nowej tożsamości bibliotekarza $w$ erze zmian technologicznych i mobilności ustug bibliotecznych, w: Biblioteka w przestrzeni edukacyjnej: bibliotekarz 2.0 - nowoczesność na bazie tradycji: II Międzynarodowa 
pomoc w rozwiewaniu niejasności. Pomoc w rozwiązywaniu problemów klienta wzbudza w nim zaufanie i sprzyja budowaniu pozytywnych relacji. Celem bibliotekarza jest dążenie do stworzenia przyjaznej, spokojnej atmosfery charakteryzującej czytelnie w bibliotekach. Komunikacja z klientem może wpływać na aktywność, zachowanie się, zadowolenie, motywację i relacje klienta $\mathrm{z}$ innymi klientami w czytelni ${ }^{24}$.

\section{Kontakt klienta z biblioteką przez katalog OPAC}

$\mathrm{Na}$ stronach internetowych bibliotek akademickich, w katalogach OPAC dostępne są specyficzne formy kontaktu przeznaczone dla klienta. Może on przekazywać do biblioteki komunikaty, innymi słowy, oficjalne wiadomości, to znaczy:

- zapisać się do biblioteki, dokonać aktywacji konta czytelniczego, zamawiać i rezerwować książki, prolongować okres wypożyczenia,

- zamawiać i opłacać kopie cyfrowe ze zbiorów bibliotecznych,

- dodawać komentarze do książki w katalogu.

Zamawianie i opłata za zeskanowanie artykułu w czasopiśmie, fragmentu książki są dostępne w katalogu OPAC dzięki aplikacji Libsmart Copy. Dodatkowym kanałem komunikacji w tym procesie jest poczta e-mail. Usługa skierowana do wszystkich zainteresowanych zarówno z Polski, jak i z innych krajów spotyka się z wzrastającym zadowoleniem klientów, czego potwierdzeniem są dokonane wpłaty, które w porównaniu z rokiem 2012 wzrosły ponad pięciokrotnie w 2014 roku $^{25}$. Usługa w wielu bibliotekach jeszcze nie jest dostępna, w niektórych można z niej korzystać dopiero od początku 2015 roku $^{26}$. Klient już nie musi bezpośrednio kontaktować się z bibliotekarzem w bibliotece, aby otrzymać książkę czy czasopismo przechowywane w magazynach bibliotecznych ${ }^{27}$, przekazuje online kolejne komunikaty intuicyjnie, bez konieczności poznawania skomplikowanych instrukcji ${ }^{28}$.

Konferencja Naukowa, Kraków 23-24 maja 2013, https://repozytorium.amu.edu.pl/handle/10593/7884 [dostęp: 10.04.2016].

${ }^{24} \mathrm{~K}$. Balawajder, Umiejętności interpersonalne w pracy menedżera, w: Psychologia w pracy menedżera, red. B. Kożusznik, Katowice 1994, s. 91.

${ }^{25}$ P. Karwasiński, H. Wesołowska-Mis, op.cit., s. 173.

${ }^{26}$ A. Peszel, Libsmart Copy, "Głos Akademicki” 2015, nr 1, s. 32.

27 Por. E. Lepkowska, G. Kostecki, Komunikacja interpersonalna a wizerunek bibliotekarza w nowoczesnej bibliotece, „Biuletyn EBIB” 2006, nr 10 (80), http://www.ebib. pl/2006/80/a.php [dostęp: 10.04.2016].

${ }^{28}$ P. Karwasiński, H. Wesołowska-Mis, op.cit., s. 172. 
Równie mało rozpowszechnionym sposobem komunikacji przez OPAC wśród bibliotek akademickich jest oferta, dzięki której klient uzupełnia opis katalogowy komentarzem. Zalogowany użytkownik w katalogu OPAC Biblioteki Politechniki Krakowskiej (https://www.biblos. pk.edu.pl/) ma możliwość udostępniania wszystkim w opisie książki komentarzy dotyczących: aktualności publikacji, oceny zawartości merytorycznej. Opinia własna pracownika, doktoranta czy studenta może okazać się użyteczna dla pracujących ze skomentowaną książką - ów komentarz w powiązaniu $\mathrm{z}$ osobą może być postrzegany za wiarygodny przez odbiorcę. Istnieje pogląd, że jednostka chętnie szuka drogi na skróty w rozwiązywaniu problemu i wykorzystuje wiarygodność nadawcy ${ }^{29}$. Imię i nazwisko autora komunikatu są widoczne w katalogu, co może przyczynić się do jego popularności wśród przeglądających opisy książek.

\section{Podsumowanie}

Zmiany w komunikacji między ludźmi pozwalają inaczej spojrzeć na proces komunikacji z klientem we współczesnej bibliotece akademickiej. Ważne są psychologiczne podejście do klienta i sposób oddziaływania na niego. Chodzi o dobrą komunikację, bez zbędnych napięć, w której odbiorca pozyskuje i zapamiętuje przekaz zrozumiały dla siebie. Znajomość schematów dobrej komunikacji oraz wyczucie sytuacji sprawiaja, że ludzie stają się komunikatywnymi, dobrymi nauczycielami.

Sposobu zachowania, reakcji w komunikacji z ludźmi można się nauczyć. W tym miejscu nasuwają się pytania, czy w bibliotece wskazuje się odpowiednie kwalifikacje, predyspozycje, jakie powinna mieć jednostka pracująca z zespołem, prowadząca szkolenia oraz zajęcia dydaktyczne, jak również czy podejmowane są działania ułatwiające komunikację z klientem.

Komunikacja społeczna rządzi się zupełnie innymi prawami, znaczenia nabrały przebywanie $\mathrm{w}$ różnych miejscach $\mathrm{w}$ Internecie, dostęp do informacji, społeczna integracja w pozytywnym znaczeniu ${ }^{30}$, otwarcie na klienta. Znajomość przyzwyczajeń klienta spędzającego dużo czasu online pozwala na dopasowanie oferty biblioteki akademickiej do jego oczekiwań, wymuszając m.in. doskonalenie katalogu OPAC w obsłudze klienta.

${ }^{29}$ D.T. Kenrick, S.L. Neuberg, R.B. Cialdini, op.cit., s. 260.

${ }^{30}$ W. Babik, Ekologia informacji w Internecie $i$ bibliotece, w: Biblioteki w świecie informacji sieciowej. Konferencja 6-7 czerwca 2013 r., red. H. Hollender, Warszawa 2014, s. 14, http://www.sbp.pl/repository/konferencje/Biblioteki_w_swiecie_komunikacji_ sieciowej.pdf [dostęp: 10.04.2016]. 
Klient oczekuje wielokanałowej komunikacji, prostego, zrozumiałego przekazu, który w przypadku biblioteki dotyczy oferty biblioteki i wiąże się z celami, dla których została ona powołana. Ważne są: dostęp online do zbiorów bibliotecznych i Internetu, zaistnienie społeczne klienta.

Dostępność różnych kanałów komunikacji i usług online w dużym stopniu ma wpływ na pozyskiwanie nowego klienta i jego zadowolenie. Coraz częściej klient zaczyna kontakt z biblioteką przez informację elektroniczną. Mimo że jest to komunikacja, w której uczestnicy nie widzą i nie słyszą siebie, a przekaz i odbiór informacji nie zachodzą w jednym czasie, następuje interakcja. Rozwój form kontaktu na potrzeby nowych specjalistycznych usług w trybie online, a przez to rozwój komunikacji pomiędzy biblioteką a klientem w dużym stopniu jest sposobem na zniesienie ograniczeń jednostki w dostępie do naukowych zasobów bibliotek.

Aby pozyskiwać nowego klienta biblioteki, potrzebne jest nowe myślenie o jego potrzebach komunikacyjnych i psychologicznych. Liczą się wygoda i komfort psychiczny w pozyskiwaniu przez niego informacji.

\section{Bibliografia}

Aronson E., Wilson T.D., Akert R.M., Psychologia społeczna: serce $i$ umyst, przeł. A. Bezwińska et al., Poznań 1997.

Babik W., Ekologia informacji w Internecie i bibliotece, w: Biblioteki w świecie informacji sieciowej. Konferencja 6-7 czerwca 2013 r., red. H. Hollender, Warszawa 2014.

Balawajder K., Umiejętności interpersonalne w pracy menedżera, w: Psychologia w pracy menedżera, red. B. Kożusznik, Katowice 1994.

Borg J., Perswazja: sztuka pozytywnego wpływania na ludzi, przeł. A. Mikołajewska, Warszawa 2011.

Dobek-Ostrowska B., Podstawy komunikowania społecznego, Wrocław 2004.

Folga A., Wptyw komunikacji interpersonalnej na wizerunek biblioteki, „Biblioteka i Edukacja" 2016, nr 9, http://www.bg.up.krakow.pl/newbie/index.php/bie/ article/view/142 [dostęp: 10.04.2016].

Griffin E., Podstawy komunikacji społecznej, przeł. O. i W. Kubińscy, M. Kacmajor, Gdańsk 2003.

Karwasińska E., Karwasiński P., Kształtowanie nowej tożsamości bibliotekarza w erze zmian technologicznych i mobilności ustug bibliotecznych, w: Biblioteka w przestrzeni edukacyjnej: bibliotekarz 2.0 - nowoczesność na bazie tradycji: II Międzynarodowa Konferencja Naukowa, Kraków 23-24 maja 2013, https://repozytorium.amu.edu. pl/handle/10593/7884 [dostęp: 10.04.2016].

Karwasiński P., Wesołowska-Mis H., Wpływ informatyzacji Biblioteki Uniwersyteckiej w Poznaniu na zmiany organizacyjne i rozwój ustug bibliotecznych, „Biblioteka" 2015, nr 19 (28), s. 159-183. 
Kenrick D.T., Neuberg S.L., Cialdini R.B., Psychologia społeczna, przeł. A. Nowak, O. Waśkiewicz, M. Trzebiatowska, M. Orski, Gdańsk 2002.

Lasswell H., The Structure and Function of Communication in Society, w: L. Bryson, The Communication of Ideas, New York 1948.

Lepkowska E., Kostecki G., Komunikacja interpersonalna a wizerunek bibliotekarza w nowoczesnej bibliotece, „Biuletyn EBIB” 2006, nr 10 (80), http://www.ebib. pl/2006/80/a.php [dostęp: 10.04.2016].

Maciejewska Ł., Urbańczyk B., Czego oczekuja użytkownicy biblioteki akademickiej w dobie informacji elektronicznej, w: Biblioteka: klucz do sukcesu użytkowników, red. M. Kocójowa, Kraków 2008, seria: ePublikacje Instytutu INiB UJ, 5, s. 42-52, http://www.inib.uj.edu.pl/wydawnictwa-iinib-uj/seria-3 [dostęp: 10.04.2016].

Peszel A., Libsmart Copy, „Głos Akademicki” 2015, nr 1, s. 32.

Rataj A., Komunikacja w organizacji [I], http://www.racjonalista.pl [dostęp: 10.04.2016].

Stewart J., Komunikacja interpersonalna: kontakt między osobami, w: Mosty zamiast murów: o komunikowaniu się między ludźmi, red. J. Stewart, przeł. J. Suchecki, Warszawa 2002.

Trzeciak S., Coaching marki osobistej, czyli kariera lidera, Sopot 2015.

Wojciechowski J., O komunikacji nieinformacyjnej, w: Biblioteka i informacja w komunikowaniu, red. M. Kocójowa, Kraków 2000.

Żukowski M., Twoja firma w social mediach: podręcznik marketingu internetowego dla małych i średnich przedsiębiorstw, Gliwice 2016.

\title{
URSZULA KNOP
}

\section{Communication with the customer in the academic library - a psychological approach}

\begin{abstract}
Aвstract. The article shows various aspects of communication between people, with a particular attention given to a customer's contact with a library with the use of new technologies. Properties of communication are presented. Communication providing a sense of psychological comfort to an individual in direct communication, communication via phone and via e-mail is discussed. A modern library customer is characterized. Customer service in the reading room in an academic library is taken into account as well as customer's contact through the OPAC catalogue.
\end{abstract}

KEY wORDS: direct communication, communication via phone, e-mail, OPAC, academic library. 